\title{
Why is there still hepatitis $C$ transmission in Australian prisons? A case report
}

\author{
Ben Harkness ${ }^{1 *} \mathbb{D}$, Michael Levy², Ruth Evans $^{1}$ and Jillian Wenke ${ }^{1}$
}

\begin{abstract}
Background: The ability to cure hepatitis C viral infection, with specific reference to the prisoner population and the prison environment, will be challenged, even if opiate replacement therapy is concurrently offered, and even if bleach is available. The missing elements, widely available in the community, are a regulated injecting equipment exchange and tattooing parlours.

Case presentation: We report a case of re-infection of hepatitis $C$ in a prisoner treated with a direct-acting antiviral. What makes this case so remarkable is that it was entirely predictable and preventable.

Conclusions: Hepatitis $C$ infection will continue to test both the strengths and the weaknesses in the relationship between health and corrective services in Australia. Nothing less than full implementation of all harm minimisation modalities will be necessary to eliminate the clinical and public health risks of hepatitis $C$ infection, both in prison and by extension into the general community.
\end{abstract}

Keywords: Hepatitis C, Prisoner health, Direct-acting antivirals, Re-infection, Needle syringe programme

\section{Background}

The ability to cure hepatitis C viral (HCV) infection, with specific reference to the prisoner population and the prison environment, will be challenged, even if opiate replacement therapy is concurrently offered, and even if bleach is available. The missing elements, widely available in the community, are a regulated injecting equipment exchange and tattooing parlours.

We report a case of re-infection of hepatitis $C$ in a prisoner treated with a direct-acting antiviral (DAA). What makes this case so remarkable is that it was entirely predictable [1] and preventable.

Treating prisoners infected with $\mathrm{HCV}$ is a priority of the Fourth Australian Hepatitis C Strategy. That document states:

'The prevalence of hepatitis $\mathrm{C}$ is disproportionately higher among people in custodial settings, due primarily to a high rate of imprisonment for drug-related offences and unsafe injecting drug use in prisons' [2].

The Australian Government's position is strongly supported by public health principles $[3,4]$.
Reasons for this sensible approach are the risks of transmission in-custody of an already highly infected population, their chaotic lifestyle in the community, associated toxicity of interferon-based treatments and their need for supervision, high rates of serious mental illness and other comorbidities. Further, DAAs have been reported to be safe and cost-effective in the prison setting [5].

On 1 March 2016, the Australian Minister for Health authorised the prescription of DAAs to Australian citizens with proven chronic hepatitis $\mathrm{C}$ infection. The Australian Medical Association has stated that funding was linked to the 'controversial axing of bulk billing incentives for pathology and diagnostic imaging services' [6]. Remarkably, and responding to clear public health imperatives, Australian prisoners were fully entitled to access publicly funded DAAs-absolutely cost-free to patients.

Australia could be a world achiever, by this early adoption of universal access to DAA medications. In contrast, in the USA, prisoners have virtually no access to these medications [7].

* Correspondence: ben.harkness@act.gov.au

'Justice Health Services, ACT Health, Canberra, Australia

Full list of author information is available at the end of the article 


\section{Case presentation}

The 39-year-old male was treated for HCV genotype 1a between weeks 4 and 16 of incarceration (12 weeks of ledipasvir and sofosbuvir). Four weeks after the therapy was finished, the patient returned a negative polymerase chain reaction (PCR) result.

The patient describes a single episode of shared injecting with a known HCV-positive contact. The episode is described with some clarity, approximately 4-6 weeks after the negative PCR result. Bleach had been accessed, and a well-described method of flushing the injecting equipment with diluted bleach was used. The patient was receiving a stable dose of $95 \mathrm{mg}$ methadone at the time.

He had been in custody for 7 months when the health service was notified that the HCV PCR result was positive. That result related to a test taken in week 30 of the period of incarceration. The genotype was reported as a mixed infection of genotype 3 and genotype 1 or 6-clearly distinct from the sample taken at pretreatment. Given the significance of that result, the sample was retested and confirmed. Liver function tests and full blood count were normal.

\section{Discussion and conclusion}

The Alexander Maconochie Centre (AMC) is presented by the Australian Capital Territory (ACT) Government as the first human rights-compliant prison in Australia. The ACT Government committed to the provision of sterile injecting equipment through a regulated needle and syringe programme (NSP) [8]. Regrettably, that announcement was premature-in 2016, custodial officers voted overwhelming to reject any proposed model, and the initiative has, to date, been buried. This NSP was to complement an opiate replacement programme and the confidential provision of bleach, both bulk liquid and in powder form packed in individual use sachets. Approximately one-third of prisoners are on methadone-maintenance therapy, including the patient in this case report.

Late relapse of $\mathrm{HCV}$ infection after DAA treatment is described [9], but we believe that we are describing an instance of re-infection, rather than relapse, for the following reasons:

- The patient completed 12 weeks of prescribed treatment with ledipasvir and sofosbuvir for genotype 1a HCV infection

- Was $100 \%$ compliant with dosing-confirmed against his medication charts

- Provides a credible history of injecting drug use between the two qualitative PCR tests (referred to as 'end-of-treatment' and 'sustained viral-response')

- The genotype change before and after treatment
Our patient was counselled that he was once again 'infectious' and that a decision to retreat would be made in 6 months' time, only once chronic infection has been determined. Interestingly, pathology taken at 6 months revealed a negative PCR result, indicating the patient had spontaneously cleared his HCV re-infection.

We believe that this case report highlights a number of health and ethical issues:

- The decision to offer prisoners equal access to DAA treatments for HCV infection was well grounded, both epidemiologically and ethically [4]

- The risk of HCV transmission, while reduced by rapid implementation of DAA treatment, was not completely eliminated and cannot be expected to be until every PCR HCV-positive patient is rendered non-infectious

- There will be ongoing 'transmission' of HCV from community to prison, with the constant flow of new receptions into custody

- Bleach availability is, at best, partially effective in reducing $\mathrm{HCV}$ transmission

- Widespread prescription of opiate replacement treatment, similarly, is demonstrated to be at best, partially effective in reducing $\mathrm{HCV}$ transmission

- A regulated injecting equipment exchange would have provided a respectful and humane choice to our case and further reduced the risk of re-infection

Hepatitis $\mathrm{C}$ infection will continue to test both the strengths and the weaknesses in the relationship between health and corrective services in Australia. Nothing less than full implementation of all harm minimisation modalities will be necessary to eliminate the clinical and public health risks of $\mathrm{HCV}$ infection, both in prison and by extension into the general community.

\section{Abbreviations}

ACT: Australian Capital Territory; AMC: Alexander Maconochie Centre; DAA: Direct-acting antiviral; HCV: Hepatitis C virus; NSP: Needle syringe programme; PCR: Polymerase chain reaction

Acknowledgements

The authors would like to acknowledge John Didlick, Hepatitis ACT.

\section{Funding}

No funding was received for research leading to or in preparation of this manuscript.

\section{Availability of data materials}

Data sharing is not applicable to this article as no datasets were generated or analysed during the current study.

\section{Authors' contributions}

JW and RE collected the necessary information including the dates of relevant events in the case report. The manuscript was written by $\mathrm{ML}$ and $\mathrm{BH}$. All authors read and approved the final manuscript. 


\section{Ethics approval and consent to participate}

A written consent was obtained from ACT Health to submit this article for publication.

\section{Consent for publication}

A written informed consent to submit this article for publication was obtained from the individual whom is the subject of this case report.

\section{Competing interests}

The authors declare that they have no competing interests.

\section{Publisher's Note}

Springer Nature remains neutral with regard to jurisdictional claims in published maps and institutional affiliations.

\section{Author details}

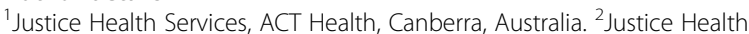

Services, ACT Health, ANU Medical School, Canberra, Australia.

Received: 6 November 2017 Accepted: 15 November 2017

Published online: 25 November 2017

\section{References}

1. Grady B, Schinkel J, Thomas X, Dalgard O. Hepatitis C virus reinfection following treatment among people who use drugs. Clin Infect Dis. 2013:57(S2):S105-10

2. Fourth National Hepatitis C Strategy 2014-2017. Australian Government. Canberra 2014 (Accessed 30 May 2017)http://www.health.gov.au/internet/ main/publishing.nsf/content/A68444CDED77B3A9CA257BF0001CFD80/\$File/ Hep-C-Strategy2014-v3.pdf

3. Martin N, Vickerman P, Dore G, Grebely J, Miners A, Cairns J, Foster G, Hutchinson S, Goldberg D, Martin T, Ramsay M, Hickman M. Prioritization of HCV treatment in the direct-acting antiviral era: an economic evaluation. J Hepatol. 2016;65(1):17-25.

4. Grebely J, Robaeys G, Bruggmann P, Aghemo A, Backmund M, Bruneau J, Byrne J, Dalgard O, Feld J, Hellard M, Hickman M, Kautz A, Litwin A, Lloyd A, Mauss S, Prins M, Swan T, Schaefer M, Taylor L, Dore G. Recommendations for the management of hepatitis $C$ virus infection among people who inject drugs. Int J Drug Policy. 2015;26:1028-38.

5. Foschi A, Casana M, Radice A, Ranieri R, Monforte A. Hepatitis C management in prisons: an insight into daily clinical practice in three major Italian correctional houses. Hepatology. 2016;64(5):1821-2.

6. Australian Medical Association. Hepatitis C Cure Could Come At A Cost. Australian Medicine (/ausmed) March 15, 2016. https:/ama.com.au/ausmed/ hepatitis-c-cure-could-come-cost (Accessed 20/06/2017).

7. Beckman A, Bilinski A, Boyko R, Camp G, Wall A, Lim J, Wang E, Bruce R, Gonsalves $G$. New hepatitis $C$ drugs are very costly and unavailable to many state prisoners. Health Aff. 2016:35(10):1893-901.

8. Sweet M. Needle and syringe exchange programme is announced for Australian prison. Br Med J. 2012;345:e5615. (published 17 August 2012)

9. Simmons B, Saleem J, Hill A, Riley R, Cooke G. Risk of late relapse or reinfection with hepatitis $C$ virus after achieving a sustained virological response: a systematic review and meta-analysis. Clin Infect Dis. 2016;62(6):683-9.

\section{Submit your next manuscript to BioMed Central and we will help you at every step:}

- We accept pre-submission inquiries

- Our selector tool helps you to find the most relevant journal

- We provide round the clock customer support

- Convenient online submission

- Thorough peer review

- Inclusion in PubMed and all major indexing services

- Maximum visibility for your research

Submit your manuscript at www.biomedcentral.com/submit 